\title{
ANALISIS NILAI-NILAI KEISLAMAN DALAM PEMBELAJARAN BAHASA INGGRIS PADA JENJANG PENDIDIKAN TSANAWIYAH DI KOTA PADANGSIDIMPUAN
}

\author{
RAYENDRIANI FAHMEI LUBIS \\ Dosen Fakultas Tarbiyah dan Ilmu Keguruan IAIN Padangsidimpuan \\ Email: rayendriani.lubis@yahoo.com
}

\begin{abstract}
This research has been done at Madrasah Tsyanawiah in Padangsidimpuanin order to know the English learning process at Madrasah Tsyanawiah, to know the learning source is used that it consists of Islamic values or not and to know learning sources based on curriculum or English teachers' attempt to colaborate based on Islamic value or not. The kind of reasearch is qualitative approach by descriptive method with the participant of this research are the English teachers and observation, interview and document are used as instrument in this research. The result showed that starting and closing learning process done by English teachers consisted of Islamic values as Ilahiah value at MTsN 1 Padangsidimpuan, MTsN Ujung Gurap, MTsS Panca Dharma and MTsS YPKS, while insaniah value has applicated at MTsS Panca Dharma. The learning sources used at MTs in Padangsidimpuan is textbook from BOS. The Learning source used consists of Ilahiah value and Insaniah value at di MTsN 1 Padangsidimpuan, MTsN Ujung Gurap dan MTsS Panca Dharma. Every English teachers in each MTs didnot have learning sources intergratedly with Islamic values yet. The teachers' reasons why they haven't done it yet because they were worry that their students can't answer UAN items and they said that UAN items don't concist of Islamic items.
\end{abstract}

Keywords: Islamic values, English lessons, Learning sources.

\begin{abstract}
Abstrak
Penelitian ini dilaksanakan di jenjang pendidikan Madrasah Tsyanawiah yang ada di kota Padangsidimpuan. Tujuan penelitian ini, yaitu untuk mengetahui bagaimana proses pembelajaran bahasa Inggris di MTs se-kota Padangsidimpuan, untuk mengetahui sumber belajar yang digunakan mengandung nilai-nilai keislaman atau tidak dan untuk mengetahui guru menggunakan sumber belajar sesuai kurikulum nasional atau ada usaha mengelaborasi sesuai nilai-nilai keislaman atau tidak. Jenis penelitian ini menggunakan pendekatan kualitatif dengan metode deskriptif. Partisipan penelitian ini, yaitu guru bahasa Inggris di Madrasah Tsyanawiah se-kota Padangsidimpuan. Observasi, wawancara dan dokumen menjadi instrumen penelitian ini. Hasil penelitian menunjukkan bahwa pada saat proses pembelajaran yang dilakukan oleh guru bahasa Inggris di dalam kelas mulai dari
\end{abstract}


108 | TAZKIR: Jurnal Penelitian Ilmu-ilmu Sosial dan Keislaman

Vol. 02 No. 2 Desember 2016

proses pembukaan pembelajaran sampai dengan proses menutup pembelajaran terdapat nilai keislaman dalam bentuk nilai Ilahiah di MTsN 1 Padangsidimpuan, MTsN Ujung Gurap, MTsS Panca Dharma dan MTsS YPKS. Sedangkan nilai keislaman dalam bentuk nilai Insaniah sudah diaplikasikan di MTsS Panca Dharma. Sumber belajar yang digunakan di MTs se-kota Padangsidimpuan berupa buku paket yang berasal dari dana BOS. Dari sumber belajar yang digunakan di dalam kelas, nilai-nilai keislaman berupa nilai Ilahiah dan nilai Insaniah terdapat pada buku paket yang digunakan di MTsN 1 Padangsidimpuan, MTsN Ujung Gurap dan MTsS Panca Dharma. Dari kelima MTs yang diteliti, guru bahasa Inggris menggunakan sumber belajar berupa buku paket yang sesuai dengan Kurikulum Nasional, tetapi guru bahasa Inggris belum mengintegrasikan materi pembelajaran bahasa Inggris dengan nilainilai keislaman. Yang menjadi alasan mereka mengapa mereka belum mengintegrasikan materi pembelajaran bahasa Inggris dengan nilai-nilai keislaman karena mereka takut dan khawatir murid-murid tidak dapat menjawab soal-soal UAN yang mana pada soal-soal UAN tidak terdapat materi yang berbau Islami walaupun soal-soal UAN tersebut diperuntukkan kepada muridmurid MTs.

Kata Kunci : Nilai-Nilai Keislaman, pembelajaran Bahasa Inggris, sumber belajar.

\section{PENDAHULUAN}

Bahasa Inggris sebagai bahasa internasional memegang peran yang sangat penting di dunia. Hampir seluruh aspek kehidupan yang ada di dunia memanfaatkan bahasa Inggris sebagai media atau alat berkomunikasi. Bahasa Inggris dipakai dalam bidang pendidikan, politik, ekonomi, sosial dan budaya.

Pemerintah Indonesia sebagai bagian dari dunia memandang bahasa Inggris sangat perlu. Bahasa Inggris harus dipahami atau dimengerti oleh seluruh bangsa Indonesia. Pemahaman ini diperlukan untuk hubungan luar negeri atau untuk menghadapi pasar bebas. Bangsa Indonesia harus bisa berkomunikasi dengan menggunakan bahasa Inggris. Melihat hal ini, maka pemerintah Indonesia merasa perlu memasukkan bahasa Inggris ke dalam kurikulum pembelajaran di sekolah-sekolah dan madrasah. Tujuan pemerintah memasukkan bahasa Inggris ke dalam kurikulum pembelajaran, yaitu agar generasi muda Indonesia bisa berkomunikasi dengan menggunakan bahasa Inggris.

Pada umumnya, bahasa Inggris diajarkan mulai tingkat SMP/Tsanawiyah, SMA/Aliyah dan Perguruan Tinggi. Di samping itu, pemerintah juga memberikan izin kepada beberapa sekolah nonformal untuk 
mendirikan kursus bahasa Inggris. Di beberapa sekolah bahasa Inggris sudah diajarkan sejak Taman Kanak-kanak (TK) dan Sekolah Dasar (SD).

Dalam proses belajar mengajar, buku ajar atau buku paket yang baik sangat dibutuhkan. Di dalam buku tersebut mencakup seluruh materi pembelajaran yang akan dipelajari murid, setiap murid wajib membaca isi buku tersebut. Ketika murid membaca buku, maka dia akan memperoleh ilmu pengetahuan dari hasil bacaannya. Setiap guru dan orang tua berharap hasil bacaan yang diperoleh murid merupakan hasil bacaan yang baik dan bermanfaat bagi murid. Dengan demikian, ilmu pengetahuan setiap murid semakin bertambah yang diharapkan dapat dibarengi sikap atau perilaku yang baik pula.

Demikian juga dengan proses belajar mengajar yang ada di sekolah Madrasah Aliyah dan Madrasah Tsyanawiah. Setiap orang tua yang mendaftarkan anaknya ke sekolah agama berharap supaya anak mereka bisa mengenal agama Islam lebih baik dan dapat mengamalkan ajarannya dengan ikhlas. Di samping pembelajaran agama Islam, murid-murid yang bersekolah di MA dan MTs juga mempelajari ilmu pengetahuan umum seperti Pancasila, Kewarganegaraan, Ilmu Pengetahuan Sosial, Sains, Matematika, Bahasa Indonesia dan Bahasa Inggris.

Pelajaran bahasa Inggris di MTs diterima murid 2x2 jam pelajaran dalam satu minggu, sekitar empat jam atau sekitar tiga jam dalam satu minggu. Proses pembelajaran berlangsung mulai kelas 1 sampai kelas 3, sekitar tiga tahun. Dalam satu minggu mereka belajar bahasa Inggris selama tiga jam, maka dalam satu tahun mereka belajar bahasa Inggris selama sembilan puluh enam hari. Selama tiga tahun mereka telah menghabiskan waktu selama delapan ratus enam puluh empat jam di sekolah belajar bahasa Inggris. Waktu tersebut merupakan waktu yang sangat panjang dan dapat membuat murid lebih mengenal dan mendalami bahasa Inggris.

Bahasa Inggris berasal dari negara Inggris yang penduduknya dominan tidak beragama Islam. Mereka terbiasa dengan kehidupan bebas, makan dan minum yang haram serta bergaul dengan yang bukan muhrim. Mereka juga menggunakan pakaian yang tidak menutup aurat. Budaya Inggris juga sangat berbeda dengan budaya Indonesia. Penduduk Inggris terbiasa dengan budaya Eropa yang serba bebas. Sementara penduduk Indonesia terbiasa dengan budaya Asia yang sopan santun dan ramah tamah. 
110 | TAZKIR: Jurnal Penelitian Ilmu-ilmu Sosial dan Keislaman

Vol. 02 No. 2 Desember 2016

Sebagai bangsa Indonesia yang berbudi pekerti luhur, sebaiknya kita mempertahankan budaya Indonesia. Bangsa Indonesia memiliki budaya dan karakter yang khas. Bangsa Indonesia tidak perlu merubah budayanya, karena budaya yang dimiliki bangsa Indonesia merupakan pemersatu rakyat Indonesia.

Belajar bahasa Inggris di MTs merupakan sebuah keniscayaan yang tidak dapat ditawar-tawar. Setiap murid di MTs wajib mengikuti pembelajaran bahasa Inggris, walaupun bahasa Inggris ini berasal dari negara Inggris yang memiliki budaya dan agama yang jauh berbeda dengan murid. Setiap murid MTs harus mengerti bahasa Inggris, karena bahasa Inggris merupakan salah satu komponen mata pelajaran yang diujikan dalam ujian Nasional (UN).

Murid yang belajar di MTs pada umumnya menganut agama Islam. Mereka mempelajari bahasa Inggris selama empat jam pelajaran dalam satu minggu. Diharapkan setiap murid MTs bisa belajar bahasa Inggris dengan baik, tapi pelajaran ini diharapkan tidak merubah keyakinan dan kebudayaan mereka. Diharapkan setiap murid MTs bisa berbahasa Inggris aktif dan pasif serta tetap menjaga budaya Indonesia, khususnya budaya Tapanuli Selatan dan tetap beriman kepada Allah SWT.

Untuk menyahuti harapan tersebut perlu ada kreatifitas guru bahasa Inggris atau kreatifitas pengarang buku bahasa Inggris di MTs. Murid dapat belajar bahasa Inggris dengan baik dengan menggunakan sumber pembelajaran yang baik seperti buku. Sebaiknya buku bahasa Inggris yang digunakan dalam proses belajar mengajar mengandung nilai budaya Indonesia dan nilai agama Islam. Peneliti ingin menganalisis tentang isi pelajaran bahasa Inggris di MTs.

Masalah-masalah ini perlu penyelesaian lebih lanjut. Ada berbagai cara untuk menyikapi masalah tersebut, diantaranya melalui kurikulum pembelajaran bahasa Inggris dan media pembelajaran bahasa Inggris. Untuk kurikulum bahasa Inggris disesuaikan dengan materi pembelajaran bahasa Inggris secara nasional, sehingga seluruh murid yang belajar di MTs memperoleh ilmu bahasa Inggris yang sama dengan murid-murid lain di Indonesia. Selanjutnya untuk sumber pembelajaran bahasa Inggris yang sama dengan kondisi Indonesia dan agama Islam, sehingga seluruh murid bisa belajar bahasa Inggris tanpa mengurangi nilai budaya Indonesia dan nilai keislaman. Sumber belajar yang digunakan masih dominan menggunakan buku yang sama dengan di SMP. Dalam hal ini, yang menjadi sorotan adalah ada atau tidaknya 
pengembangan pembelajaran dengan kata lain kreatifitas guru yang merubah unsur ke Islaman.

Dari uraian di atas, peneliti menganggap bahwa perlu ada penelitian lebih dalam tentang proses pembelajaran bahasa Inggris di MTs. Murid MTs khusnya murid MTs di kota Padangsidimpuan. Isi pelajaran bahasa Inggris yang mereka pelajari dapat dilihat dari kurikulum dan buku pelajaran bahasa Inggris yang mereka gunakan ketika belajar di kelas. Buku pelajaran bahasa Inggris memberikan gambaran tentang materi-materi yang dipelajari murid MTs mulai kelas satu hingga kelas tiga. Oleh karena itu, penelitian memilih judul Analisis Nilai-nilai Keislaman dalam Pembelajaran Bahasa Inggris pada Jenjang Pendidikan Tsyanawiyah di Kota Padangsidimpuan.

\section{TINJAUAN PUSTAKA}

\section{Nilai-nilai Keislaman}

1. Pengertian Nilai-nilai Keislaman

Menurut Zakiah Darajat, mendefinisikan nilai adalah suatu perangkat keyakinan atau perasaan yang diyakini sebagai suatu identitas yang memberikan corak yang khusus kepada pola pemikiran dan perasaan, keterikatan maupun perilaku. ${ }^{1}$ Dan menurut Mulyana, nilai adalah suatu keyakinan yang membuat seseorang bertindak atas dasar pilihannya, sebagai normatif yang mempengaruhi manusia dalam menentukan pilihannya di antara cara-cara tindakan alternatif, sebagai keyakinan individu secara psikologis atau nilai patokan normatif secara sosiologis dan sebagai konsepsi (sifatnya membedakan individu atau kelompok) dari apa yang mempengaruhi pilihan terhadap cara, tujuan antara dan akhir tindakan. ${ }^{2}$

Menurut Yusuf al-Qardhawi, nilai keislaman adalah pendidikan manusia seutuhnya, akal dan hatinya, rohani dan jasmaninya, akhlak serta keterampilannya. ${ }^{3}$ Sedangkan Hasan Langgulung merumuskan nilai keislaman adalah proses penyiapan generasi muda untuk mengisi peranan, memindahkan pengetahuan dan nilai-nilai Islam ang diselaraskan dengan fungsi manusia untuk beramal di dunia dan memetik hasilnya di akhirat. ${ }^{4}$

1 Zakiah Darajat, Dasar-dasar Agama Islam, (Jakarta: Bulan Bintang, 1984), h. 260.

2 Zubaedi, Desain Pendidikan Karakter Konsepsi dan Aplikasina dalam Lembaga Pendidikan, (Jakarta: Kencana, 2011), hlm. 35.

${ }^{3}$ Azamardi Azra, Pendidikan Islam Tradisi dan Modernisasi di Tengah Tantangan Milenium III, (Jakarta: Kencana, 2012), hlm. 6.

${ }^{4}$ Ibid., hlm. 6. 
Dengan demikian, dapat disimpulkan bahwa nilai keislaman adalah nilai pendidikan ang diselenggarakan atau didirikan dengan hasrat dan niat untuk mengamalkan ajaran dan nilai-nilai Islam. ${ }^{5}$

2. Nilai yang Terkandung Dalam Agama Islam

Adapun nilai-nilai Islam apabila ditinjau dari sumbernya, maka dapat digolongkan menjadi dua macam, yaitu:

a. Nilai Ilahi

Nilai Ilahi adalah nilai yang bersumber dari Al-Qur'an dan hadits. Nilai ilahi dalam aspek teologi (kaidah keimanan) tidak akan pernah mengalami perubahan, dan tidak berkecenderungan untuk berubah atau mengikuti selera hawa nafsu manusia. Sedangkan aspek alamiahnya dapat mengalami perubahan sesuai dengan zaman dan lingkungannnya.

b. Nilai Insani

Nilai insani adalah nilai yang tumbuh dan berkembang atas kesepakatan manusia. Nilai insani ini akan terus berkembang ke arah yang lebih maju dan lebih tinggi. Nilai ini bersumber dari ra'yu, adat istiadat dan kenyataan alam. ${ }^{6}$ Bila ditinjau dari orientasinya, nilai dikategorikan kedalam empat bentuk nilai yaitu:

c. Nilai etis

Nilai etis adalah nilai yang mendasari orientasinya pada ukuran baik dan buruk.

d. Nilai Pragmatis

Nilai Pragmatis adalah nilai yang mendasari orientasinya pada berhasil atau gagalnya.

e. Nilai Efek Sensorik

Nilai efek sensorik adalah nilai yang mendasari orientasinya pada hal yang menyenangkan atau menyedihkan.

f. Nilai Religius

Nilai religius adalah nilai yang mendasari orientasinya pada dosa dan pahala, halal dan haramnya.

3. Landasan Nilai-nilai Keislaman

${ }^{5}$ Muhaimin, Rekonstruksi Pendidikan Islam, (Jakarta: PT. Raja Grafindo Persada, 2009), hlm. 14.

${ }^{6}$ Muhaimin, Abd. Mujib, Pemikiran Pendidikan Islam, (Bandung: Bumi Aksara, 1991), hlm. 111. 
Landasan atau dasar nilai-nilai Keislaman dapat dibagi menjadi dua kategori, yaitu:

a. Dasar pokok, yakni meliputi Al-Qur'an dan hadits

1) Al-Qur'an

Al-qur'an adalah firman Allah berupa wahyu yang disampaikan oleh Jibril kepada Nabi Muhammad SAW. Ajaran yang terkandung didalam Al-Qur'an itu terdiri terdiri dari dua prinsip besar, yaitu yang berhubungan dengan masalah keimanan yang disebut aqidah, dan yang berhubungan dengan amal yag disebut syari'ah. ${ }^{7}$

2) Sunnah

As-sunnah adalah perkataan, perbuatan ataupun pengakuan Rasulullah SAW. Yang dimaksud dengfan pengakuan itu adalah kejadian atau perbuatan orang lain yang diketahui Rasulullah dan beliau membiarkan saja kejadian atau perbuatan itu berjalan.

b. Dasar tambahan

1) Perkataan, perbuatan, dan sikap para sahabat

Pada masa khulafaul Rasyidin sumber pendidikan dalam Islam sudah mengalami perkembangan. Selain Al-Qur'an dan Sunnah juga perkataan, sikap, dan perbuatan para sahabat.

2) Ijtihad

Ijtihad adalah istilah para fuqaha', yaitu berpikir dengan menggunakan seluruh ilmu yang dimiliki oleh ilmuwan syariat Islam untuk menetapkan atau menentukan suatu hukum syariat Islam dalam hal-hal yang ternyata belum ditegaskan hukumnya oleh AlQur'an dan Sunnah.

3) Maslahah Mursalah

Maslahah mursalah adalah menetapkan peraturan atau ketetapan undang-undang yang tidak disebutkan dalam Al-Qur'an dan sunnah atas pertimbangan penarikan kebaikan dan menghindarkan kerusakan. ${ }^{8}$

${ }^{7}$ Zakiah Daradjat, Ilmu Pendidikan Islam, ( Jakarta: Bumu Aksara, 2006), hlm. 31.

${ }^{8}$ Mustafa Zaid, Al-mashlahah fi al-Islami wa Najmudin al-Thufi wa an-Nasyar, (Mishr: Dar alFikr, 1964), hlm. 149. 
114 | TAZKIR: Jurnal Penelitian Ilmu-ilmu Sosial dan Keislaman

Vol. 02 No. 2 Desember 2016

\section{Bahasa Inggris}

1. Pengertian Bahasa

Bahasa adalah sistem yang teratur berupa lambang-lambang bunyi yang digunakan untuk mengekspresikan perasaan dan pikiran bahasa tersebut. Menurut Syamsuddin ada dua pengertian definisi bahasa, yaitu bahasa adalah alat yang dipakai untuk membentuk pikiran dan perasaan, keinginan dan perbuatan-perbuatan, alat yang dipakai untuk mempengaruhi dan dipengaruhi. Dan Bahasa adalah tanda yang jelas dari kepribadian yang baik maupun yang buruk, tanda yang jelas dari budi kemanusiaan. ${ }^{9}$

Abdul Chaer dan Leonie Agustina menyebutkan hakikat bahasa dalam buku "Pragmatik: Perkenalan Awal" yaitu sebuah sistem, artinya, bahasa itu dibentuk oleh sejumlah komponen yang berpola secara tetap dan dapat dikaidahkan. ${ }^{10}$

2. Prinsip Dasar Bahasa

Anderson mengemukakan ada delapan prinsip dasar bahasa:

1. Bahasa adalah suastu sistem

2. Bahasa adalah vokal (bunyi ujaran)

3. Bahasa tersusun dari lambang-lambang arbitrer

4. Setiap bahasa bersifat unik (khas)

5. Bahasa dibangun dari kebiasaan-kebiasaan

6. Bahasa adalah alat komunikasi

7. Bahasa berhubungan erat dengan budaya tempatnya berada

8. Bahasa selalu berubah-ubah. ${ }^{11}$

3. Batasan Bahasa

H. Douglas Brown menelaah batasan bahasa dari enam sumber, yaitu:

a. Bahasa adalah suatu sistem yang sistematis, barangkali juga untuk sistem generatif.

b. Bahasa adalah seperangkat lambang-lambang mana suka atau simbolsimbol arbitrer.

c. Lambang-lambang atau simbol-simbol tersebut menagndung makna konvensional.

hlm 2.

${ }_{9}^{9}$ Syamsuddin, A.R., Sanggar Bahasa Indonesia, (Jakarta: Universitas Terbuka Jakarta, 1986),

${ }^{10}$ Abdul Chaer, Linguistik Umum, (Jakarta: Rineka Cipta, 1994), h. 2.

${ }^{11}$ Hendry Guntur Tarigan, Pengajaran Kompetensi Bahasa, (Bandung: Angkasa, 1986), hlm. 3. 
d. Bahasa beroperasi dalam satu masyarakat bahasa (a speech community) atau budaya.

e. Bahasa dipergunakan sebagai alat kominikasi atau sarana pergaulan sesama insan manusia.

f. Bahasa pada hakikatnya bersifat manusiawi, walaupun mungkin tidak terbatas pada manusia saja.

g. Bahasa diperoleh semua orang/bangsa dengan cara yang hampir/banyak bersamaan, bahasa dam pembelajaran bahasa mempunyai ciri-ciri kesemestaan. ${ }^{12}$

4. Fungsi Bahasa

Menurut Wilkins ada delapan kategori fungsi bahasa dalam kaitannya dengan kategori fungsi komunikasi, yaitu:

a. Modalitas, yaitu pengekpresian (tingkat-tingkat) kepastian, pengekspresian keperluan dan pendirian.

b. Disiplin dan evaluasi moral, aitu pengekspresian kesetujuan dan ketidaksetujuan).

c. Suasi/bujukan, yaitu meyakinkan, mengajurkan, mendorong.

d. Argumen, yaitu menjelaskan, menerangkan, memperbedebatkan, menentang dan menegaskan.

e. Inkuiri dan eksposisi rasional, yaitu mengekspresikan implikasiimplikasi, memberikan contoh dan membatasi.

f. Emosi-emosi personal, aitu mengekspresikan kesenangan, keheranan, kekagetan dan kejengkelan.

g. Relasi-relasi emosional, misalnya menyapa, mengekspresikan rasa sukur dan terima kasih.

h. Relasi-relasi interpersonal, yaitu mengekspresikan tingkat-tingkat formalitas dan keramahtamaan. ${ }^{13}$

5. Pemakaian Bahasa

Malinowski mengatakan bahwa makna datang bukan dari pe renungan yang pasif terhadap kata, tatapi justru dari analisis fungsinya yang beraneka ragam dengan mengacu kepada kebudayaan tertentu. Beliau membedakan enam tipe penggunaan atau pemakaian bahasa (six types of language use), yaitu: ${ }^{14}$

a. Pragmatic use (pemakaian pragmatik)

b. Narrative use (pemakaian naratif)

${ }^{12}$ H. Douglas Brown, Principles of Language Learning and Teaching, (New Jersey: Prentice Hall, 1980), hlm. 5.

${ }^{13}$ Wilkins D., Notional Syllabuses, (Oxford: Oxford University Press, 1976), h. 35.

${ }^{14}$ Ibid., hlm. 67. 
116 | TAZKIR: Jurnal Penelitian Ilmu-ilmu Sosial dan Keislaman

Vol. 02 No. 2 Desember 2016

c. Ritual (magic) use (pemakaian ritual magik)

d. Scholastic use (pemakaian skolastik)

e. Theological use (pemakaian teologis)

f. Scientific use (pemakaian ilmiah)

6. Keterampilan Berbahasa

Keterampilan berbahasa dapat dibedakan menjadi dua bagian, yaitu:

a. Keterampilan produktif (productive skill)

Keterampilan produktif meliputi keterampilan menulis (writing skill) dan keterampilan berbicara (speaking skill).

b. Keterampilan reseptif (receiptive skill)

Keterampilan reseptif meliputi keterampila menyimak/mendengarkan (listening skill) dan keterampilan membaca (reading skill).

\section{METODE PENELITIAN}

Penilitian ini dilakukan di sekolah tingkat Madrasah Tsyanawiah (MTs) yang berada di kota Padangsidimpuan, Sumatera Utara, yaitu MTsN 1 Padangsidimpuan, MTsN 2 Padangsidimpuan, MTsN Ujung Gurap, MTs Swasta Panca Dharma dan MTs Swasta YPKS (Yayasan Pendidikan Karya Setia). Penelitian ini telah dilakukan pada bulan April 2016 sampai pada bulan Oktober 2016. Penelitian ini menggunakan pendekatan kualitatif dengan metode deskriptif. Guru bahasa Inggris dan murid kelas I, II dan III merupakan sumber data primer pada penilitian ini. Sedangkan kepala sekolah dan buku paket di sekolah yang menjadi data skunder. Metode pengumpulan data yang dimaksud, yaitu observasi, dokumen dan wawancara. Teknik analisis data yang peneliti gunakan adalah metode analisis data deskriptif, karena penelitian ini bertujuan untuk mendiskripsikan nilai-nilai keislaman yang terdapat di dalam pembelajaran bahasa Inggris di kota Padangsidimpuan.

\section{HASIL PENELITIAN DAN PEMBAHASAN}

\section{Proses Pembelajaran}

Pada saat proses pembelajaran yang dilakukan oleh guru bahasa Inggris di dalam kelas mulai dari proses pembukaan pembelajaran sampai dengan proses menutup pembelajaran terdapat beberapa guru bahasa Inggris yang telah menerapkan nilai-nilai keislaman seperti nilai Ilahiah dan nilai Insaniah. Nilainilai keislaman tersebut diapplikasikan oleh guru bahasa Inggris dengan mengucapkan salam pada saat membuka dengan ucapan Assalamualaikum Wr. $\mathrm{Wb}$ dan guru juga mengucapkan Alhamdullilah serta salam pada saat menutup 
proses pembelajaran di dalam kelas, mengingatkan para murid untik senantiasa patuh dan patuh kepada guru, guru meningatkan bahwa semua yang ada di duniaini merupakan ciptaan Allah SWT serta mempersilahkan para murid untuk melakukan shalat pada waktunya. Tetapi dan juga beberapa guru bahasa Inggris yang belum menerapkan nilai-nilai keislaman pada saat proses pembelajaran. Guru tersebut membuka proses pembelajaran dengan mengucapkan salam How are you dan tidak menutup proses pembelajaran dengan mengucapkan Hamdallah maupun salam. Guru tersebut juga tidak memberi nasehat, perhatian serta teguran kepada murid di saat murid-murid ribut di dalam kelas atau melakukan kegiatan dan hal-hal yang tidak baik dan sopan di dalam kelas misalnya murid mengganggu temannya saat belajar, bercermin di sudut belakang kelas pada saat proses pembelajaran sehingga murid tersebut tidak mendengarkan penjelasan guru dan murid sesuka hati masuk dan keluar kelas tanpa permisi. Semua itu terjadi dikarenakan kurangnya nasehat, arahan serta perhatian guru terhadap murid-muridnya.

\section{Sumber Belajar}

Sumber belajar yang digunakan di MTs se-kota Padangsidimpuan pada proses pembelajaran bahasa Inggris berupa buku paket. Buku paket tersebut berasal dari dana BOS. Buku tersebut dibagikan pada murid-murid pada saat proses pembelajaran saja dan pada proses pembelajaran selesai maka buku paket dikembalikan lagi kepada guru untuk disimpan dan dipergunakan kembali pada saat proses pembelajaran bahasa Inggris sesuai dengan roster. Buku paket yang digunakan memiliki judul dan pengarang ang berbeda-beda pada masingmasing sekolah. Sayangnya terdapat buku paket yang tidak sama judul dan pengarangnya pada satu sekolah, yaitu pada MTsN Ujung Gurap.

Dari sumber belajar yang digunakan di dalam kelas, nilai-nilai keislaman berupa nilai Ilahiah dan nilai Insaniah terdapat pada buku paket yang digunakan. Nilai-nilai keislaman tersebut terlihat pada gambar-gambar yang terdapat di dalam buku paket yang mana ada wanita yang mengenakan jilbab saat berbicara dengan temannya, ada seorang guru yang mengajar dengan mengenakan jilbab dan begitu pula dengan murid pada gambar juga mengenakan jilbab. Tetapi nilai-nilai keislaman tersebut tidak terdapat di semua buku paket, ada buku paket yang sama sekali tidak mengandung nilai-nilai keislaman. Buku paket tersebut memuat gambar yang memperlihatkan aurat 
118 | TAZKIR: Jurnal Penelitian Ilmu-ilmu Sosial dan Keislaman Vol. 02 No. 2 Desember 2016

dengan mengenakan pakaian yang tidak berlengan alias You can see dan menggunakan senjata.

Kondisi ini mencerminkan bahwa sekolah-sekolah Islam tanpa sengaja mengadaptasi buku-buku pembelajaran bahasa Inggris di sekolah umum. Apabila guru-guru di MTs terlanjur membeli buku-buku tersebut, guru masih punya kesempatan mengintegrasikan nilai-nilai keislaman dalam pembelajaran bahasa Inggrisdengan cara mengganti teks-teks yang ada di buku dengan teksteks yang Islami yanga dapat dituangkan dalam RPP setiap guru.

\section{Usaha Guru Mengintegrasikan Nilai-Nilai Keislaman dalam Sumber Belajar Bahasa Inggris}

Secara keseluruhan semua guru di sekolah MTs yang diobservasi belum mengintegrasikan nilai-nilai keislaman dalam materi pembelajaran bahasa Inggris. Pada umumnya mereka mengajar sesuai dengan buku bahasa Inggris yang ada di sekolah. Setiap sekolah memiliki buku yang berbeda. Orientasi pembelajaran masih fokus pada kurikulum nasional dan kemampuan murid menyelesaikan soal bahasa Inggris pada saat UAN. Orientasi pembelajaran belum terarah ke pembentukan karakter Isalami dan keahlian bahasa Inggris.

\section{PENUTUP}

Dari hasil penelitian, peneliti dapat menyimpulkan beberapa kesimpulan yang berkenaan dengan rumusan masalah serta tujuan penelitian. Beberapa kesimpulan yang dimaksud sebagai berikut:

1. Proses Pembelajaran

Pada saat proses pembelajaran yang dilakukan oleh guru bahasa Inggris di dalam kelas mulai dari proses pembukaan pembelajaran sampai dengan proses menutup pembelajaran terdapat nilai keislaman dalam bentuk nilai Ilahiah di MTsN 1 Padangsidimpuan, MTsN Ujung Gurap, MTsS Panca Dharma dan MTsS YPKS. Sedangkan nilai kaislaman dalam bentuk nilai Insaniah sudah diaplikasikan di MTsS Panca Dharma.

2. Sumber Belajar

Sumber belajar yang digunakan di MTs se-kota Padangsidimpuan berupa buku paket yang berasal dari dana BOS. Buku-buku tersebut diberikan kepada murid-murid hanya di saat proses pembelajaran berlangsung, setelah 
pembelajaran usai buku paket dikembalikan kepada guru untuk disimpan. Sayangnya, buku paket hanya dapat di berikan satu eksemplar untuk dua murid. Hal ini dikarenakan jumlah buku paket tidak sesuai dengan jumlah murid-murid yang ada di dalam kelas. Dan ada hal lain lagi yang menjadi masalah, yaitu buku paket yang digunakan di MTsN Ujung Gurap berbedabeda. Dari sumber belajar yang digunakan di dalam kelas, nilai-nilai keislaman berupa nilai Ilahiah dan nilai Insaniah terdapat pada buku paket yang digunakan di MTsN 1 Padangsidimpuan, MTsN Ujung Gurap dan MTsS Panca Dharma.

3. Sumber Belajar Sesuai dengan Kurikulum Nasional dan Usaha Guru Mengintegrasikan Nilai-nilai Keislaman dalam Sumber Belajar.

Dari kelima MTs yang diteliti, guru bahasa Inggris menggunakan sumber belajar berupa buku paket yang sesuai dengan Kurikulum Nasional, tetapi guru bahasa Inggris belum mengintegrasikan materi pembelajaran bahasa Inggris dengan nilai-nilai keislaman. Yang menjadi alasan mereka mengapa mereka belum mengintegrasikan materi pembelajaran bahasa Inggris dengan nilai-nilai keislaman karena mereka takut dan khawatir murid-murid tidak dapat menjawab soal-soal UAN yang mana pada soal-soal UAN tidak terdapat materi yang berbau Islami walaupun soal-soal UAN tersebut diperuntukkan kepada murid-murid MTs. 
120 | TAZKIR: Jurnal Penelitian Ilmu-ilmu Sosial dan Keislaman

Vol. 02 No. 2 Desember 2016

\section{DAFTAR RUJUKAN}

A.R., Syamsuddin. 1986. Sanggar Bahasa Indonesia. Jakarta: Universitas Terbuka Jakarta.

Anderson, Paul S. 1972. Language Skills in Elementary Education. New York: Macmillan Publishing Co., Inc.

Arifin, M. 1993. Filsafat Pendidikan Islam, Jakarta: Bumi Aksara.

Azra, Azamardi. 2012. Pendidikan Islam Tradisi dan Modernisasi di Tengah Tantangan Milenium III. Jakarta: Kencana.

Azwar, Saifuddin. 2004. Metode Penelitian. Yogyakarta: Pustaka Pelajar.

Brown, H. Douglas. 1980. Principles of Language Learning and Teaching. New Jersey: Prentice Hall.

Chaer, Abdul. 1994. Linguistik Umum. Jakarta: Rineka Cipta.

D., Wilkins. 1976. Notional Syllabuses. Oxford: Oxford University Press.

Darajat, Zakiah. 1984. Dasar-dasar Agama Islam. Jakarta: Bulan Bintang. 2006. Ilmu Pendidikan Islam. Jakarta: Bumi Aksara.

Faisal, Mohammad. 2000. MetodePenelitan. Jakarta: Ghalia Indonesia.

Finochiaro, Mary \& Michael Bonomo. 1973. The Foreign Language Learner: A Guide for Teacher. New York: Regents Publishing Company, Inc

Haryadi dan Zamzani. 2000. Peningkatan Keterampilan Berbahasa Indonesia. Departemen Pendidikan dan Kebudayaan Direktorat Jenderal Pendidikan Tinggi.

Kamus Besar Indonesia Edisi Kedua. 1991. Departemen Pendidikan dan Kebudayaan: Balai Pustaka.

Khlal, Abdul Wahab. 1978. Ilmu Ushul al-Figh. Al-Qabbah Ath-Thab'ah wa an.

Mishbah, M. Taqi. 1984. Monoteisme Sebagai Sistem Nilai dan Aqidah Islam. Jakarta: Lentera.

Moleong, Lexy J. 2000. Metodologi Penelitian Kualitatif. Bandung: Rosdakarya. 
Muhaimin. 2009. Rekonstruksi Pendidikan Islam. Jakarta: PT. Raja Grafindo Persada.

Mujib, Muhaimin Abd. 1991. Pemikiran Pendidikan Islam, Bandung: Bumi Aksara.

Noor, Juliansah. 2013. Metodologi Penelitian:Skripsi, Tesis, Disertasi dan Kara Ilmiah. Jakarta: Kencana.

Ogden \& Richards 1987. Longman Dictionary of Applied Linguistics. London: Longman.

R.C., Bogdan, \& Biklen. SK.1982. Qualitative Research for Education. Boston: Allysand Beacon.

Riyanto, Slamet. 2015. The Practice of Teaching English Panduan Praktis Terampil Mengajar Bahasa Inggris dengan Kreatif di Sekolah, Yogyakarta: Andi Yogyakarta.

Saebani, Beni Ahmad \& Hendra Akhdiyat. 2009. Ilmu Pendidikan Islam. Bandung: CV. Pustaka Setia.

Sauri, Sofyan. 2011. Revitalisasi Pendidikan Sains dalam Pembentukan Karakter Anak Bangsa untuk Menghadapi Tantangan Global. Makalah dalam file. upi.edu.

Slamet, St. Y. dan Amir. 1996. Peningkatan Keterampilan Berbahasa Indonesia (Bahasa Lisan dan Bahasa Tertulis). Surakarta: Universitas Sebelas Maret.

Sugiyono. 2008. Metode Penelitian Pendidikan: Pendekatan Kuantitatif, Kualitatif, dan $R$ \& D. Bandung: AlFabeta.

Suyanto, Kasihani K.E. 2008. English for Young Learners, Jakarta: Bumi Aksara.

Tarigan, Hendry Guntur. 1986. Pengajaran Kompetensi Bahasa. Bandung: Angkasa. 2008. Berbicara Sebagai Suatu Keterampilan Berbahasa. Bandung: Angkasa. Angkasa.

1986. Menyimak Sebagai Suatu Keterampilan Berbahasa. Bandung: 1990. Membaca Sebagai Suatu Keterampilan Berbahasa,. Bandung: Angkasa.

Zaid, Mustafa . 1964. Al-mashlahah fi al-Islami wa Najmudin al-Thufi wa an-Nasyar. Mishr: Dar al-Fikrr 
122 | TAZKIR: Jurnal Penelitian Ilmu-ilmu Sosial dan Keislaman Vol. 02 No. 2 Desember 2016

Zaidan, Jarji. Tarikh Al-Tamaddun al-Islam. Dar Al-Maktabah Al-Hayat, tt.

Zubaedi. 2011. Desain Pendidikan Karakter Konsepsi dan Aplikasina dalam Lembaga Pendidikan. Jakarta: Kencana. 